\title{
THE ASYMMETRIC ACQUISITION HYPOTHESIS IN THE INITIAL STAGES OF CHILD AND ADULT L2 DEVELOPMENT OF ENGLISH
}

\author{
Ana Lazarova-Nikovska \\ FON University, Skopje \\ ana.lazarova-nikovska@fon.edu.mk
}

The purpose of the current paper is to contribute to L2A research by exploring the age effects in the initial stages of L2 morphosyntactic development. It predominantly assumes the generative framework of grammar and language acquisition, where direct L2 child-adult comparison has been a neglected area of research, producing several theoretical assumptions, supported by rare and contradictory empirical work. In the current paper, the initial age effects are investigated in the light of learners' morphosyntactic L2A. More specifically, the $[ \pm$ strong] Infl parameter of UG, V-raising in particular, is taken as the linguistic element of investigation, since it assigns different values in English [- strong] and in Macedonian [+ strong].

The participants in the experiment are a group of children (age 8-11) and a group of adults (age 20-60), all native speakers of Macedonian and beginners of L2 English. They were tested after a four-week exposure to specifically designed instruction on English V-raising.

In the paper, it is argued that L2 children and adults share both similarities and qualitative differences in the early stages of L2A. The two age groups are similar in the syntactic L2 development, while they differ in the acquisition of inflectional morphology on thematic verbs, where only L2 adults show considerable difficulties (supporting the Asymmetric Acquisition Hypothesis). They both seem to differ from children acquiring English as their mother tongue.

Key words: second language acquisition, age effects, morphosyntax, Asymmetric Acquisition Hypothesis 


\title{
ХИПОТЕЗАТА ЗА АСИМЕТРИЧНО УСВОЈУВАЊЕ НА НЕМАЈЧИН ЈАЗИК ВО ПОЧЕТНИТЕ СТАДИУМИ НА ЈАЗИЧЕН РАЗВОЈ КАЈ ДЕЦА И ВОЗРАСНИ
}

\author{
Ана Лазарова-Никовска \\ Универзитет ФОН, Скопје \\ ana.lazarova-nikovska@fon.edu.mk
}

Целта на овој труд е да даде придонес кон истражувањата во областа усвојување на немајчин јазик преку анализа на ефектите на возраста во почетните стадиуми на морфосинтаксичкиот развој на немајчиниот јазик. Пишуван е во генеративната теориска рамка за граматика и усвојување јазик, во која директно споредување на деца и возрасни изучувачи на немајчин јазик ретко се истражувало, од што се произлезени неколку теориски хипотези, поддржани со контрадикторни емпириски резултати. Во конкретниот труд, почетните ефекти на возраста се проучувани низ призма на морфосинтаксичкиот развој на јазикот цел. Поконкретно, [ \pm strong] параметарот на универзалната граматика и поместувањето на лексичкиот глагол (V-raising) се земени како предмет на лингвистичка анализа, бидејќи овој параметар има различни вредности во двата јазика, [- strong] во англискиот и [+ strong] во македонскиот јазик.

Учесници во експерименталниот дел од трудот се група деца (возраст 8-11 години) и група возрасни (возраст 20-60 години), сите родени говорители на македонскиот јазик и почетници во изучувањето на англискиот јазик. Тестирани беа по четиринеделна настава на англиски јазик, специјално создадена со фокус на (не)поместувањето на лексичкиот глагол (V-raising), како феномен во англискиот јазик.

Заклучокот во трудот е дека децата и возрасните усвојувачи на немајчин јазик делат сличности, но и квалитативни разлики во почетните фази на овој развоен процес. Двете возрасни групи се слични во синтаксичкиот развој на јазикот цел, додека пак се разликуваат во усвојувањето на морфолошките наставки на лексичките глаголи, при што само возрасните изучувачи покажуваат значителни тешкотии (со што се поддржува хипотезата за асиметрично усвојување). И двете групи, пак, се разликуваат во развојот на овој јазичен елемент, од деца кои го усвојуваат англискиот јазик како мајчин.

Клучни зборови: усвојување немајчин јазик, ефекти на возраста, морфосинтакса, хипотеза за асиметрично усвојување 


\section{Introduction}

In language acquisition research, the age factor has been in the centre of a heated debate for more than 50 years. It has often been observed, both in theory and practice, that the outcome of second language acquisition (L2A) in adulthood does not always resemble that of first language acquisition (L1A) or child L2A. Such realisations have urged theorists and researchers to postulate a biologically determined period that governs language acquisition, most known as the Critical Period Hypothesis (CPH) for language learning.

This phenomenon has been discussed, explicitly or implicitly, in many theoretical frameworks and evidence has been put forward to either support or reject its existence. Moreover, sceptics of a biologically determined critical period have offered a range of alternative explanations to account for the attested child-adult differences, especially in second language (L2) development.

The research surrounding the $\mathrm{CPH}$ debate has usually relied on measuring general proficiency levels for the purpose of establishing child-adult differences in L2A. Nowadays, a more detailed investigation of learners' interlanguage is encouraged. When rooted in specific theoretical assumptions, such analysis would provide insight into the underlying language learning processes of children and adults. The rationale is that similar results between children and adults would be viewed as an argument against the $\mathrm{CPH}$, whereas qualitative differences in the nature of their interlanguage would offer support for the existence of the CPH in L2A. The utmost purpose of the current study is to add its contribution to such quest for the answer surrounding the role of the $\mathrm{CPH}$ in L2A. It does so by comparing the interlanguage of a group of children and adults, in strictly controlled experimental conditions and in a formal language learning environment. Any pedagogical implications that may arise from the outcome should be only taken as speculative and offer directions for future research, of a primarily methodological nature.

In this paper we primarily analyse the generative debate surrounding childadult differences in the initial stages of L2 morphosyntactic development. The paper is organised as follows: In Section 2 a general overview is offered on the age differences in L2A. Section 3 focuses on the generative theory of L2A and the conflicting arguments for child L2 and adult L2 acquisition are presented and illustrated, being summarised in the Asymmetric acquisition hypothesis, testing with the current experiment. Section 4 introduces V-raising as the linguistic element subject of investigation in this paper. The experimental design as well as 
the results of the current study are discussed in Section 5. The final conclusions arising both from the literature review surveyed in the paper and the test results of the experiment are presented in Section 6.

\section{The critical period hypothesis in second language acquisition}

Based on neurological evidence and parallel to the existence of biological critical periods in other species, Penfield and Roberts (1959) and Lenneberg (1967) suggested a critical period for language learning in humans. The strictly biological definition of the critical period, according to which language acquisition must happen within a clearly defined period of time, in childhood, or it will never happen at all, is unsustainable, at least for L2 development, as empirical evidence largely suggests. Therefore, a 'weaker version' of the critical period, namely the Sensitive Period Hypothesis (SPH) for language learning (Immelmann and Suomi 1981; Lamendella 1977; Patkowski 1990) is nowadays more commonly used and tested in the context of L2A. Unlike the $\mathrm{CPH}$, the SPH is a gradual process, without sharply defined lower and upper limits, a time of heightened responsiveness to certain environmental stimuli. Accordingly, language acquisition is possible after puberty, albeit it is a cumbersome and an incomplete process. A number of various ages in the life of an individual have been suggested as marking the beginning and the end of the sensitive period. For Long (1990), for example, the ability to achieve native-like levels in phonology starts to decline at the age of 6 , whereas it ends at 12 , while the terminus for morphosyntax is believed to be age 15 .

In the quest for evidence of the $\mathrm{CPH}$, research has emerged that yielded quite contradictory results, with the older learners outperforming the younger in some studies, whereas in others, the younger learners achieve better results than the older ones. Krashen et al. $(1979,1982)$, surveying then the existing research on the age factor in L2A, concluded that the situation might not be as unclear as it seemed since the majority of studies could be divided in two main groups: a) long-term studies and b) short-term studies. Based on these two broad divisions and considering the ages of the participants in the studies, the authors offered the following generalisations:

1. Adults proceed through early stages of syntactic and morphological development faster than children (where time and exposure are held constant);

2. Older children acquire faster than younger children (again, in early stages of morphological and syntactic development where time and exposure are held constant); 
3. Acquirers who begin natural exposure to second languages during childhood generally achieve higher levels of second language proficiency than those beginning as adults (Krashen, Long and Scarcella 1982, 161).

The $\mathrm{CPH}$ continues to be an intriguing topic among researchers in L2A, with some purporting that we should look into a series of age factors, rather than search for a single biological cause (Birdsong 2018; Singleton 2005), while others have also focused on the implications of the existence of such 'window of opportunity' for all aspects of classroom settings, from the implementation of an early start, to the assessment methods, and the possible effect on the L1, among others (de Bot 2014; Nikolov and Mihaljević Djigunović 2006).

\section{The age issue within the generative approach}

Within the generative framework for second language acquisition, the issue of the $\mathrm{CPH}$ has been originally linked with the availability of Universal Grammar $(\mathrm{UG})^{1}$, understood as an innate predisposition for language learning. The simplistic argument has been that UG is accessible to L2 learners if there is no critical period $(\mathrm{L} 1 \mathrm{~A}=\mathrm{L} 2 \mathrm{~A})$, i.e. Full access to $U G$ in $\mathrm{L} 2 \mathrm{~A}$, whereas it is inaccessible to $\mathrm{L} 2$ learners in the existence of a critical period ( $\mathrm{L} 1 \mathrm{~A} \neq \mathrm{L} 2 \mathrm{~A})$, i.e. No Access to $U G$ in L2A. However, what was really being compared in these theories was L1A with adult L2A, while direct comparison of L2 children and adults has been a less common research combination. Empirical work on the L2A of children has been largely neglected under the assumption that L2 children have access to UG. Unfortunately, there are very few UG-based studies that directly compare child L2 and adult L2 development (Schwartz 2003; White 1996).

The few studies that directly compare L2 children and adults yield contradictory results, with Hilles (1991), for example, arguing for different interlanguage representations between L2 children and L2 adults, whereas Epstein et al. (1996) for similar developmental patterns between the two age groups of second language learners. For example, Epstein et al. (1996), using an elicited imitation technique, directly compared the proficiency levels of a group of Japanese child (age 6-10) and adult (age 22-36) second language learners of English. The objective of the study was to test for the existence of functional

\footnotetext{
1 The generative approach to LA is part of the Nativist theories of language, which argue for the existence of an innate Language Acquisition Device (LAD) and/or Universal Grammar. The poverty of the stimulus and the complexity and uniqueness of human language are the reasons why it is believed that UG guides L1A. Similar assumptions are put forward for the process of L2A (e.g. Chomsky 1986a; White 2003b).
} 
categories in what the authors believed to be the initial stages of L2A. The results of the experiment were almost identical for both age groups, with better results in tests on elements related to the Inflectional Phrase (IP), rather than on those belonging to the Complementiser Phrase (CP). However, exposure to the L2 input was different for the two age groups, thus rendering the evaluation of the direct group comparison rather difficult. It is also argued that the learners represented intermediate, rather than early stages of development. Furthermore, the scarce L2 child-adult comparative research that exists is also subjected to methodological limitations, such as: unequal language input between the two groups, relying on data originally gathered not to test a UG prediction, and lack of proper adult subjects in one of the proficiency levels tested, among others.

In the absence of explicit generative theories for child-adult differences in L2A, the following two inferences can be made: Position $A$ [Child L1 = Child L2 \# Adult L2] and Position $B$ [Child L1 = Child L2 = Adult L2]. These hypotheses refer to the developmental process of L2A in general, without making specific distinctions between different language areas, such as syntax and morphology.

Assuming the workings of UG in L2A, one specific claim put forward by Schwartz (2003) is that child and adult L2 learners have equal syntactic, but different morphological development. Schwartz (2003: 46) further explains: "L2 adults asymmetrically acquire grammar, such that inflectional morphology typically lags behind syntax, sometimes even dramatically." Moreover, with respect to comparison with the process of $\mathrm{L} 1 \mathrm{~A}$, it is also argued that the syntactic development of both child and adult L2 learners is believed to be different from that of L1 learners, whereas only adults' morphological development differs from that of $\mathrm{L} 1$ acquirers. This position on L2 child-adult differences is known as the Asymmetric Acquisition Hypothesis (AAH) [Child L1A $\neq$ (Child L2A = Adult L2A) for syntax] and [(Child L1A = Child L2A) $\neq$ Adult L2A) for morphology]. Schwartz bases the Asymmetric Acquisition Hypothesis on already existing studies, i.e. Unsworth (2002a,b) for the L2A of syntax and on Bisschop (1998), Punt (1998) and Weerman (2002) for the L2A of morphology.

Employing a combination of a truth value judgment task and an elicited production task, Unsworth (2002b) investigated the acquisition of scrambling of direct objects in L2 Dutch by child and adult native speakers of English, a language with no scrambling. She used definite direct objects (NPs) in her tests as scrambling (movement) of the object over the sentential adverbial is obligatory in such context in L2 Dutch. The results of Unsworth's research showed that L2 children and L2 adults follow the same developmental pattern in syntactic L2A, based on the acquisition of definite NP scrambling. Moreover, comparison with the acquisition of scrambling by L1 Dutch learners (based on Schaeffer 2000) was conducted and it was concluded that the developmental route of child L2 learners is distinct from that of L1 acquirers: the L2 children initially produced 
NegVO as well as both NegVO and NegOV sentences, a developmental pattern not found in L1A of this phenomenon in Dutch. Unsworth (op.cit.) analysed such results as showing L1 influence even with the L2 child learners.

Unfortunately, Unsworth's project did not include adult participants for the earliest stages of development, as a result of the already higher proficiency score of this age group at the time testing began. Therefore, direct comparison of children and adults at the commencement of L2A was impossible. Apart from the lack of comparative evidence from the early stages of L2 development, L2 children and adults were compared in all other stages where they followed the same developmental path.

In the domain of morphology, Weerman (2002), together with his students Bisschop (1998) and Punt (1998), report on a comparative study on the acquisition of adjectival inflection in Dutch by L1 and L2 children as well as L2 adults. The L2 learners in this study came from different L1 backgrounds. In Dutch, attributive adjectives are always inflected except when they modify a singular indefinite neuter gender noun, i.e. a het-noun. The Weerman group found that first and child second language acquirers produce similar types of errors throughout the developmental stages recorded in the study. Nevertheless, the two groups of children differed in their final state of L2A since only the L2 children (but not the L1 children) continued to overgeneralise the inflected adjective in the context of singular indefinite het-nouns even after 11 years of exposure to the target language. On the other hand, the adult L2 learners showed more variability in the errors they made in comparison to both groups of children and also incorrectly overgeneralised the uninflected form of the attributive adjective with indefinite common gender nouns (i.e. de-nouns), a phenomenon found neither with the L1 nor with the child L2 acquirers.

It can be argued, however, that differences in the time of exposure to Dutch make the comparison among the groups quite inadequate, hence the results can only be regarded as tentative. The L1 children were exposed to Dutch for a period of $3-7$ years. The L2 children had lived in the Netherlands for between 11 and 18 years at the time of data collection, while the majority of L2 adults only between $18-32$ months. Just 2 out of the 14 adults were immersed in the L2 input for longer ( 7 years and 18 years, respectively).

Hence, the L2 children were tested at quite an advanced state of L2 development, in comparison to the L1 children. Had the child L2 learners been tested at an earlier stage, more comparable to that of the child L1 acquirers, they might have produced other interlanguage errors, not documented with the L1 acquirers. Nevertheless, ignoring this remark, the conclusion drawn was that only child L2A is similar to child L1A, at least in the types of errors made and in the early and intermediate stages of acquisition. 
Regarding the comparison of the L2 children with the L2 adults, it can again be argued that the children were not tested at an early enough stage in order to be equitably compared to the 'relatively' initial stages the majority of adults represented. Had they been tested in earlier stages of development, the L2 children could have made additional errors, and similar to the ones reported to be unique to the adult group. In a discussion of this study, Schwartz (2003) also comments that the results are imperfect, yet suggestive that L2 children and L2 adults follow different developmental patterns in the acquisition of target-like inflectional morphology, with only L2 children being similar to first language acquirers.

To summarise, the topic of the paper, age effects in the initial stages of L2A, is explored in light of the following hypothesis: L2 children and adults have similar syntactic, but different morphological development (Asymmetric Acquisition Hypothesis), using new experimental conditions:

a. The L2 syntactic and morphological developments are directly compared in a single study;

b. A new language pair is used in the comparison, L1 Macedonian - L2 English;

c. New language domains are used in the comparison, V-raising for the syntax and verbal inflection for the morphology;

d. The L2 children and adults are compared in the initial stages of L2A.

Moreover, the language domains and the type of morphological test used in this study enable us to further investigate the interdependence of syntax and overt morphology as well as to gather a better insight into L2 adults' difficulty with inflectional morphology.

In the next section we introduce the grammatical domain tested with the experiment.

\section{The linguistic background}

Within the Principles and Parameters model of generative grammar, parametric differences are associated with the UG lexicon, namely with functional categories (DP, IP, CP). Such parametric differences between languages usually have overt syntactic consequences.

For example, an abstract feature representing tense-agreement morphology originates in the lexicon and is situated in syntax under Inflection (Infl/I). In one language this feature carries the value [strong], whereas in other the feature carries the value [weak]. Such differences have word order consequences 
evidenced through V-movement. If Infl is strong, it attracts the Verb, if it is weak it does not attract it and the verb must remain in the head of the verb phrase (VP) (Haegeman 1994; Pollock 1989). This type of movement is called V-raising and the parametric difference is referred to as $[ \pm$ strong Infl].

Languages differ in respect to the heads that are allowed to raise to a higher head position in the structure. In languages such as English lexical verbs do not move to Infl. Only auxiliary verbs and modals do. On the other hand, languages such as Macedonian or French, allow verb movement with all verb types.

English and Macedonian have different settings for the $[ \pm$ strong Infl] parameter, [- strong] in English and [+ strong] in Macedonian. These two different values of the parameter are believed to have empirical consequences which confirm the existence of V-movement in a language. They are the relative position of main verbs and auxiliaries in the following structures: negation, question formation (i.e. subject-verb inversion) and possibly adverbs and floating quantifiers (Culicover 1997).

In this paper, we explore the first two consequences, negation and question formation based on the behaviour of three verbs in these structures, copula be, modal can and main verbs (with $d o$-support) in present tense. In English, there is a syntactic distinction between auxiliaries/modals (non-thematic verbs) and lexical (thematic) verbs. Such distinction does not exist in Macedonian. Moreover, the forms of present tense copula be in Macedonian are clitics. Therefore, they need a host and cannot stand on their own in the sentence structure. The negative marker ne is also a clitic.

The following are examples of the most typical negative and interrogative sentence structures in both languages:

English Negation:

(1a) David is not an engineer.

(2a) Leena cannot speak Japanese.

(3a) He does not eat red meat.

\section{Macedonian Negation:}

(1b) Тоа не е возможно.

it not be-3sg possible

'It is not possible.'

(2b) Јана не може да пишува.

Jana not can-3sg subj.mark. write-3sg

'Jana cannot write.'

(3b) Мартин не јаде супа.

Martin not eat-3sg soup

'Martin does not eat soup.' 
English Questions:

(4a) Are the children at home?

(5a) Can you drive a motorcycle?

(6a) Do they live in Barcelona?

(7a) When does the train arrive?

\section{Macedonian Questions:}

(4b) Дали е Ана на училиште?

Q-part is-3sgCL Ana at school

'Is Ana at school?'

(5b) Дали Игор може да дојде со нас? Q-part can Igor subj.mark.come with us

'Can Igor come with us?'

(6b) Свири Тео клавир?

play-3sg Teo piano-the

'Does Teo play the piano?'

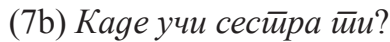

where study-3sg sister Gen-CL

'Where does your sister study?'

In this syntactic approach, negative and interrogative sentences are theoretically connected, in that only those verb types that are allowed to rise over Negation to IP (auxiliaries and modals in a [-strong Infl] language) can further rise over the grammatical subject, to an even higher position in the sentence structure (CP). In IP, the agreement features of the verb are checked, whereas in $\mathrm{CP}$ in questions the interrogative features under $\mathrm{C}$.

As Macedonian is a [+ strong Infl] language, Macedonian learners of English are expected to unlearn V-raising in their L2A of English. They should syntactically distinguish auxiliaries/modals from main verbs and refuse lexical verb raising, but rather use $d o$-support as a carrier of the inflection features of the verb. Their knowledge of these characteristics of the English language would yield higher scores on tests of Negation and Question Formation.

Parameters are said to be re-set on the basis of evidence from the L2 input. Certain elements in the input act as triggers for parameter (re)-setting. In the example of Verb Movement, where the Infl value must be reset from strong to weak, once the learners realise that $d o$ is semantically vacuous, then such input may indicate that lexical verbs cannot raise, since the only reason for the presence of this auxiliary is to carry tense and agreement features (White 2003: 163).

Although it is outside the scope of the current paper to review the studies on V-raising in L2A, it would suffice to mention that among the best known studies on V-raising in L2A of English are those by Lydia White (1990/1991, 1992) who tested whether francophone children, L2ers of English in the beginning stages of development would acquire two of the theoretically assumed clustering properties of Verb Movement (questions and adverb placement). The results were 
negative. The main finding was that instruction on one aspect of the parameter did not seem to generalise to other aspects. With respect to L1A of English, although we have not come across a study where the development of negation and questions has been directly compared, it can be safely assumed that Tense, Agreement and Complementiser should be acquired more or less at the same stage of development, also supported by empirical data (Bloom and Lahey 1978, Radford 1990, 1992).

In the next section, we proceed to stating the experiental conidtions used in the current study, followed by presenting the relevant results and discussion of them.

\section{The experiment}

\subsection{Participants}

A group of 32 adults (age 20-60) and a group of 30 children (age 8-11), all native speakers of Macedonian, took part in the experiment. They were recruited via an open call for participant volunteers who would fulfil the necessary experimental requirements, such as no previous knowledge of English. This was also checked prior to the start of the experiment. During instruction, each age group was further divided in two groups in order to reduce the number of students in class and thus increase instruction efficiency. All participants were beginners of English as none of them had a formal tuition in English prior to the experiment, nor naturalistic exposure to the target language. In each age group, about half of them were male, half female and there was a good balance of different social backgrounds. In respect to levels of formal education, all subjects in the adult group had obtained either high school diplomas or higher education degrees. Last but not least, and as mentioned above, the subjects were all volunteers and thus motivated to take part in the project. Their enduring motivation levels were also visible throughout the experimental period as their activity levels during the classes were continually high.

As the closure of the critical period for morpho-syntax is believed to be around the age of 15 (Long 1990), the age range of the children group taking part in this experiment, 8 to 11 , is considered to be within the limits of the critical period for syntax. Another practical reason is the fact that written tests in English were used in the experiment and Macedonian children start learning the Latin alphabet at the age of 7-8. The starting age of 20 for the adult group was decided on the grounds of it being outside the critical period by all definitions, i.e. beyond puberty. 


\subsection{Method and materials}

All groups underwent a four week instruction in elementary English, with a carefully and specifically prepared teaching material. The teaching material included lessons (texts and exercises) which were created for the sole purposes of the experiment and which included the target grammatical structures. Over the instruction period, each group received classes of 90 minutes, twice a week.

The teaching methodology was explicit instruction of theoretically chosen elements of the Inflectional system (I-system) in English within the context of meaningful lexical topics. The emphasis was on V-movement in negation and in questions, different in English and in Macedonian. Negation and question formation were being taught using these verb types: copula be; modal can and main verbs.

No explicit negative evidence was given to students during the instruction period, i.e. they were never told why a certain non target-like answer they would provide was incorrect in the L2. Rather, the correct answer was repeated.

Each verb type was covered by presenting and practicing the following: a text introduced by the relevant verb type and presented predominantly in the two grammatical structures (negation and questions); drills to practice both reading in general and the grammar of the particular verb type; $10-15$ minutes of explicit instruction on the grammatical focus of interest; one or two exercises eliciting negation and questions formation, again using the relevant verb. The range of exercises per verb type were covered over two classes, i.e., in one week. The last week of teaching was used for revision. We would like to clarify that we are aware that the chosen teaching approach was perhaps not the most favoured or appropriate for the children participants. With young learners, especially, when grammar is concerned, a more holistic approach should be preferred, with focus on meaning and communication and allowing the grammar to emerge from such comprehensible input. However, one needs to bear in mind the primary purpose of the current research, and that was to compare the grammatical competence between two different age groups of learners. Moreover, the instruction period was very short and care was taken that the experimental variables were as controlled between the age groups as possible, in order to increase the validity of the results and their interpretability in relation to the age factor. In such short instruction period, direct attention to the target form needed to be drawn, rather than allowing the possibility for the structures to be implicitly acquired. All this left little room for flexibility and adjustment of the teaching methods. A common ground between the two age groups needed to be found. This was considerably achieved by using meaningful texts set in familiar contexts to introduce the grammatical structures, by designing exercises in the form of meaningful dialogues and by using minimum metalanguage in class, despite the 
fact that there was direct emphasis on focus on form. Such measures ensured that the classes had a communicative flair to them and the ongoing feedback from the students, including the young learners, was such that they did not find the approach cognitively a strain. We would also like to state that the same teacher taught both age groups. The teacher was qualified and experienced for the task.

Several types of teaching materials were used for the instruction:

a. Handouts which were used for work in class only. They contained the texts for each lesson;

b. Other handouts, containing only the new vocabulary for each lesson, which participants were allowed to take home.

c. Mini posters explaining the grammar and presenting example sentences;

d. An informal final textbook which was given to each candidate upon completion of the course. It included all the texts, grammatical explanations and some additional useful texts.

Endeavours were made to maintain the amount of relevant input and relevant practice at a constant level between the groups. This was achieved by presenting both age groups with texts that contained the same amount of testing structures as well as the same amount and type of exercises to practice each structure. The fact that adults are faster readers and therefore usually covered the relevant material quicker during class was accounted for by introducing more vocabulary during the classes with this group of learners. Such lexical texts contained no grammar and were meant to be 'time-fillers' (e.g. days of the week, months of the year, etc.). Therefore, the groups inevitably differed only in the size of vocabulary and the lexical topics covered, which were accommodated to the age of the subjects in order to attract and maintain their interest.

\subsection{Tests}

A series of tests were administered in the two weeks following the teaching period. One of their purposes was to assess subjects' knowledge of the L2. Subjects were always provided with a number of examples prior to testing, which were worked through with the experimenter, after which they proceeded to the task at their own pace. In order to avoid test-bias and reduce the cognitive burden that the tests may have posed on the children group, during the instruction period, all participants were trained to do Grammatical Judgement Tests and were therefore familiarised with the type of exercises that appeared in the final test. However, exact sentences from the texts (i.e. containing the same vocabulary) were not used in the tests, in order to avoid the possibility of subjects having memorised 
the sentences without understanding the grammar involved. To further make the tests more accessible to absolute beginners, the instructions were written in Macedonian.

These tests were unpaced. The children group usually took about thirty minutes longer than the adult group, whereas the subjects within each group took about the same time to complete the tests.

A Grammaticality Judgment Task (GJT) was used to measure learners' knowledge of L2 Negation and Question Formation (consequences of the V-raising phenomenon).

Students were presented with a list of 78 sentences (39 per structure, Negation and Questions), each of which had to be judged. Of the total number of sentences, 30 were grammatical in the target language (15 per structure), 30 were ungrammatical and L1-like (15 per structure), and 18 were neither like the L2 not like the L1 (9 per structure). Each verb type presented to students during the instruction period (be, can, main verb) was tested in five different contexts, both for negation and for question formation, hence 15 grammatical and ungrammatical sentences per structure. Learners were given a three-point scale for their choice of judgement on each sentence: a) correct in English; b) don't know; and c) incorrect in English (see Appendix 1). Although it is methodologically debatable what the real reason is behind someone's decision to mark a sentence as 'don't know', in this analysis, we have decided to consider such answers as synonymous with 'incorrect' rather than with 'correct'. This is based on the fact that subjects were not given any negative evidence in the instruction, therefore, they could not have been expected to know for sure if a sentence was grammatical or not. It was thought to be sufficient that they at least showed doubt over the grammaticality of the ungrammatical sentences and decided not to mark them as being correct in the L2.

\subsection{Results and discussion}

A possible immediate effect of the L2 input is predicted by all the theories of the initial state, hence some L2 learning is expected even after a relatively short period of instruction. The main purpose of the analyses in section 5 is to test the Asymmetric Acquisition Hypothesis that L2 children and adults have similar syntactic, but different morphological development. In section 5.4.1 we present the results of learners' target-like performance in Negation (IP) and Questions (CP). For that purpose, the results for all verb types were combined to give the overall learners' performance in a language structure. Subjects were given a score if they judged correctly the grammatical sentences (circled answer option 'correct') and correctly rejected the ungrammatical sentences (circled answer 
option 'don't know' or 'incorrect'). Non-parametric tests are used in the analysis of the results.

\subsubsection{Between group analysis on the syntactic L2 development}

Figure 1 displays the target-like performance for the children and the adult group on Negation (IP domain) and Question Formations (CP domain).

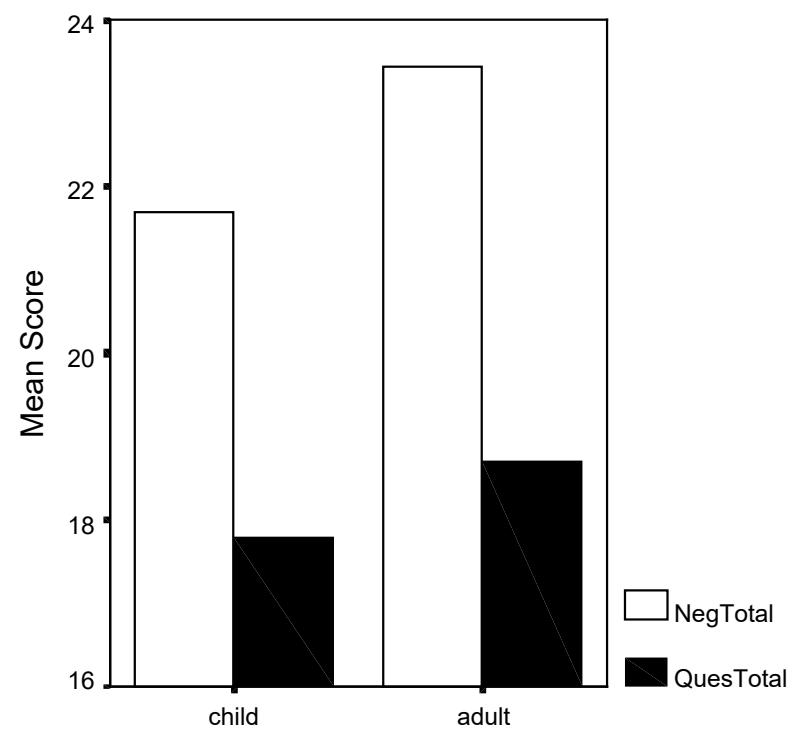

Group

Figure 1. Accuracy scores on L2 Negation and Question formation

Although the mean for the adult group is bigger than the one for the children group, the Mann-Whitney test for independent samples shows no significant difference in the performance scores between the two groups for either of the two structures. Even more striking is the mean difference between the scores on Negation and the scores on Question formation for both age groups. A within group analysis, using Wilcoxon Signed Rank Test was carried out and the results indicate a significantly higher scores in Negation than in Question formation, both for the children $(Z=-3.203, \mathrm{p}<.002)$ and for the adults $(Z=-3.867$, $\mathrm{p}<.0005)$. It is interesting to note that such statistically similar results between the L2 children and adults are not compatible with Krashen et al.'s generalisation for an initial advantage for the adults (section 2 above). 
Although this is not a longitudinal study, we may assume that both age groups are following the same path in restructuring of their grammar towards the L2 parametric value, [-strong Infl]. Such results seem to offer support for Schwartz $(1992,2003)$ in assuming that child L2 and adult L2 syntactic acquisition go through similar developmental stages. As we saw earlier (Radford 1990,1992), it is believed that native learners of English acquire Negation and Questions simultaneously, once functional categories emerge. That is not the case with the results in this study and such finding is also compatible with the second part of Schwartz's argument, namely that both child L2 and adult L2 acquisition would differ from child L1A.

In regard to the difference between IP and CP, similar results were previously obtained by Epstein et al. (1996) but not by White (1990/1991, 1992). Epstein et al. (1996) argue that one of the reasons for the lower performance on CPs is due to processing difficulties associated with long-distance movement. That is, error rate increases with the increased number of boundaries crossed in the movement. Such explanation is particularly plausible considering the testing methodology they have adopted, namely elicited imitation, where production in the L2 is required, imposing processing difficulties with CPs. An additional reason they propose is lack of syntactic wh-movement in the learners' L1 grammar of their participants (Japanese). In White's findings, on the other hand, the similarity between the scores on Negation and Questions may have been due to the fact that the learners were not tested in early enough stages. If they had been examined earlier, a difference between Negation and Question might have been observed. However, by the time they were tested, the L2 acquisition on these two structures was statistically indistinguishable. Moreover, French and English are more similar (they both have syntactic $w h$-movement) in comparison to Japanese and English (only the latter has it). This may be one of the reasons why White (ibid.) and Epstein et al. (ibid.) have obtained different results.

Epstein et al.'s explanation may provide an insight to the results in our study. However, further to being more demanding on the processing capacities, movement of the verb to $\mathrm{CP}$ requires knowledge of additional formal feature satisfaction. Namely, the finite verb being in I does not imply that it must proceed to $\mathrm{C}$. Movement is imposed by the specifications of the strong lexical features $[\mathrm{Q}$, wh] under $\mathrm{C}$ requiring to be satisfied by an element carrying that feature. That element is the finite verb in English. Therefore, it must raise to $\mathrm{C}$ in questions.

In sum, we may also presuppose that negation is acquired before questions as the latter requires the projection of a higher functional category $(\mathrm{CP})$, an additional movement operation of the verbs (from I to C) and satisfaction of additional grammatical features (i.e. of $[+Q]$ and $[+w h]$ for question formation). As such, it appears to be structurally more complex than negation. 
Furthermore, the configuration of learners' L1 may play a role in determining the different development of negation and questions evidenced in the current experiment. Firstly, in Macedonian, Negation is not as good as empirical test for V-raising as Question formation is, since verbs never raise above the negative element, while they can raise above the subject in interrogative sentences. Therefore, these L2 learners may treat the two structures in the target language separately. But even if this was the case, we still need to understand why they found Negation easier to do than Questions, considering possible mother tongue influence. The explanation may be as follows:

Regarding negation, although the learners may initially analyse $n e$ as a clitic preceding the verb, the possible and frequent presence of a range of proclitics between the negative particle and the tensed verb in Macedonian, may have helped them to notice that the English negative element not is a free phonological word and therefore does not always piggy-back ride with the verb. For example:

Тој не му г̄o gage палтото.

he not him-DatCl it- $\mathrm{AccCl}$ give coat-DEF

'He did not give him his coat'.

Therefore, unlearning of the clitichood of $n e$ seems to have proven rather unproblematic for these L2 learners.

On the other hand, based on L1-L2 comparison, there were more things that L2ers needed to unlearn in Questions:

a. Raising of the verb either to Comp or to Foc in interrogative sentences, which is possible due to the strong Infl setting of this parameter in Macedonian;

b. Availability of Q-particles in Macedonian yes-no questions; and

c. The syntactic consequences of the clitichood of copula sum, namely that in Macedonian it cannot stand phonologically unsupported under C.

All of the above may be considered as potential explanations behind the significantly worse performance on CP as opposed to IP in this experiment.

Note, however, that the instruction period in this study might have been too short to allow any parametric restructuring and therefore a fairer comparison will be not at the level of structure, but rather, at the level of verb types. White suggested that dummy do may be the syntactic trigger for (re)-setting of the V-movement parameter in English. Subsequent analysis of these learners' interlanguage might demonstrate that the children group has higher scores on sentences with $d o$-support and therefore, in that respect, resemble the process of L1A more than the L2 adult group. 


\subsubsection{Between group analysis on the morphological L2 development}

Parallel to the syntactic analysis above, in order to test the learners' overall performance in L2 morphology, the results for all verb types (be, can, main verb) were combined (Morphology Total). The results are presented in Figure 2 below. There were nine sentences testing morphology, three with each verb (Appendix 2).

Contrary to the results in Figure 1, there is a greater difference between the two groups in Figure 2 ( $80 \%$ for the children and $62 \%$ for the adults). Indeed, a Mann-Whitney test confirmed that the difference between the overall morphological results of the two groups is statistically significant, $Z=-3.417, p$ $=.001$.

The overall morphological results presented in Figure 2 imply that $\mathrm{L} 2$ children and adults follow different processes in the acquisition of L2 morphology. However, the supporters of the AAH maintain that the acquisition of inflectional morphology lags behind the acquisition of syntax with adult L2 learners. Thus, in order to examine more thoroughly the $\mathrm{AAH}$, the target scores on morphology with main verbs need to be isolated from the target scores on morphology with be and can. To this detailed morphological analysis we turn next.

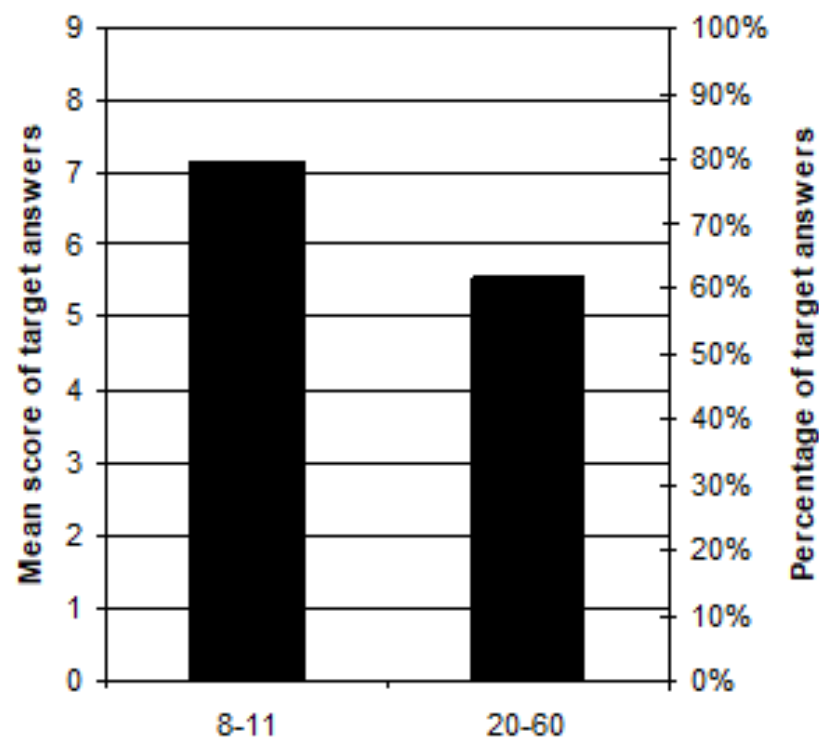

Age group

Figure 2. Target performance in Morphology Total 
Figure 3 displays the target-like morphological scores for each verb (be, can, main verb). There were three sentences testing the morphological knowledge for each verb (Appendix 2). For this analysis, a Bonferroni adjusted alpha level (.02) is a better indicator of significance than the ordinary .05 alpha level, as the analysis presupposes a multiple comparison among three verbs $(.05 / 3)$.

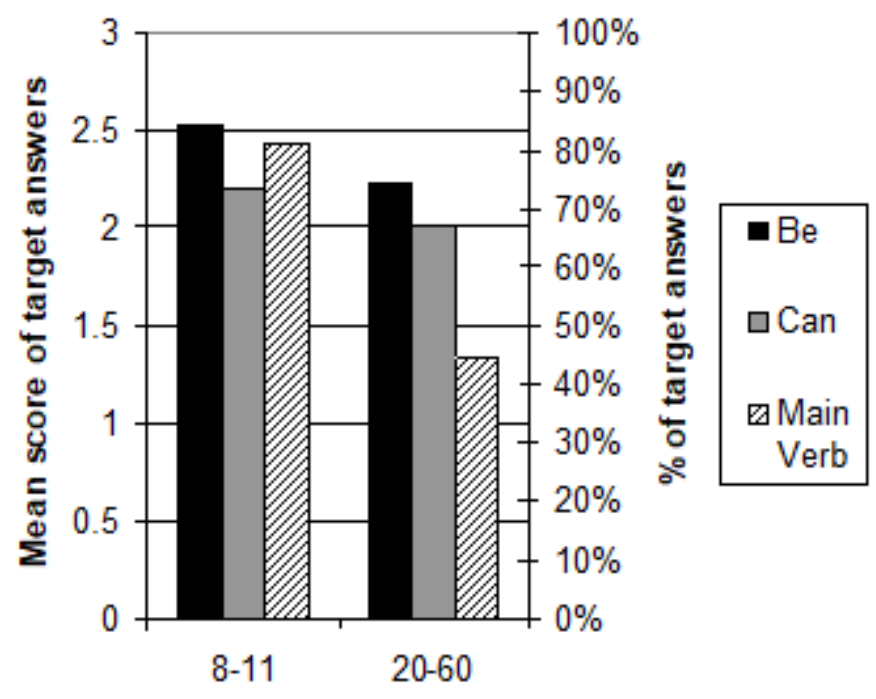

Age group

Figure 3. Target performance per verb in Morphology

Mann-Whitney tests were performed to examine the difference between the two age groups on their morphological target results for each verb and indicated that the children have significantly higher scores than the adults for morphology with main verbs, i.e. for knowledge of $3^{\text {rd }}$ person singular $[-s]$ on main verbs, with children scoring a mean of $81 \%$ correct and adults substantially less, at $44 \%$ $(Z=-3.525, p<.001)$. There was no significant difference for the other two verb types.

On the basis of the between-group comparison in L2 syntax and morphology, the current results offer support for the Asymmetric Acquisition Hypothesis: while the syntactic L2 development of children and adults is similar, their morphological development is not. And this discrepancy is mainly due to the adults' lower score in inflectional morphology. 
The reason behind the relative ease with which children acquire inflectional morphology, as opposed to the adults, is still an open question in L2A research. It may be the case that the suggested Less is More hypothesis (Newport 1990) is indeed active for children, as they pay more attention to details in the language input. At the same time, adults are more consciously concerned with the communicative aspect of language learning and therefore pay more attention to words and word orders, rather than to bound morphemes. Alternatively, the problem may reside elsewhere, perhaps in adults' non-target representation of the bound affix, even if the affix is noticed in the input. In other words, although adults notice 's' in its overt phonological or orthographic form, they cannot readily imprint the bundle of functional features for that affix in their mental Lexicon. Hence, they find the affix difficult to recall for activation, even if they use other language items in the conversation which summon the compulsory use of 's'.

\section{Conclusion}

In this paper support was offered for the Asymmetric Acquisition Hypothesis, advocated by Schwartz (2003), that child L2 and adult L2 follow similar syntactic L2 developmental pattern, but both groups differ in the acquisition of L2 morphology, where adults show statistically slower progress in the mastery of inflectional morphology.

Although this is a short-term study and represents only the earliest stages of L2A, such qualitative, short-term analysis comparing the interlanguage of children and adults at various proficiency levels can be as important in determining the existence of the $\mathrm{CPH}$ as long-term studies are believed to be. Any qualitative difference established in the initial stages of L2A may therefore yield answers to the qualitative differences in the ultimate attainment and contribute to better understanding of the process of L2A in general. In the current study, even in the context of both groups being exposed to explicit L2 instruction, it seems that only with the L2 children there was greater implicit language processing, i.e. they were able to process the affix at a deeper level and establish more firmly the link between the abstract feature and its phonetic form. This age group difference does not necessarily denote that L2 adults cannot re-set parameters: it may only take them longer or they may use an alternative route.

Despite the fact that the primary contribution of the current results is hoped to be mainly theoretical, a number of pedagogical implications also arise. A comment can be made about the textbooks generally used in EFL classes for beginners. Grammatical content differs widely between textbooks used for children and those used for adults. In fact, the same grammar that is usually 
covered over a period of six months in adult EFL classes is taught only after years of classroom instruction with children. The experiment in the current study shows that, in the early stages of L2A, children are capable of managing and analysing much more L2 input than they have been given credit for, whereas not all adults would benefit from the intense syllabus, usually planned for adult EFL classes. It was also assumed above that the two age groups may be utilising different learning processes, more implicit for the children and explicit for the adults, implying that the EFL settings for each age group should accommodate for such learning styles.

Despite the importance of meticulous interlanguage studies, it is worth emphasising that in second language acquisition, exploring the language learning processes of children and adults requires an interdisciplinary approach, which would welcome input from psychology, sociology and neurology in addition to that of linguistics, in order to better understand the interplay of the biological and non-maturational factors.

\section{References}

Birdsong, D. (2018). Plasticity, variability and age in second language acquisition and bilingualism. Frontiers in Psychology, 9: 1-17.

Bisschop, J. (1998). Verschille in verwerving: Adjectivale flexie bie eerste en tweede taalverwervers an het Nederlands [Differences in acquisition: Adjectival inflection in first and second language learners of Dutch]. MA thesis. Utrecht: University of Utrecht.

Bloom, L. and Lahey, M. (1978). Language development and language disorders. New York: John Wiley.

Chomsky, N. (1986). Knowledge of language: its nature, origin and use. New York: Praeger.

Culicover, P. W. (1997). Principles and parameters: An introduction to syntactic theory. Oxford: Oxford University Press.

De Bot, K. (2014). The effectiveness of early foreign language learning in the Netherlands. Studies in Second Language Learning and Teaching, 4(3): 409-18.

Epstein, S., Flynn, S. and Martohardjono, G. (1996). Second language acquisition: theoretical and experimental issues in contemporary research. Brain and Behavioral Sciences, 19: 677-758.

Haegeman, L. (1994). Introduction to government and binding theory. Oxford: Blackwell. Hilles, S. (1991). Access to Universal Grammar in second language acquisition. In L. Eubank (ed.). Point counterpoint: Universal Grammar in second language acquisition, 305-338. Amsterdam: John Benjamin Publishers.

Immelmann, K. and Suomi. S. (1981). Sensitive phases in development. In K. Immelmann et al. (eds.) Behavioral development, 395-431. The Bielefelt interdisciplinary project. Cambridge: Cambridge University Press. 
Krashen, S. D., Long, M. and Scarcella, R. C. (1979). Age, rate and eventual attainment in second language acquisition. TESOL Quarterly, 13: 573-82. Reprinted in Krashen, S. D., R. C. Scarcella and M. Long (eds.). (1982). Child-adult differences in second language acquisition. Rowley, MA: Newbury House Publishers, Inc.

Krashen, S. D., Scarcella, R. C. and Long, M. (eds.) (1982). Child-adult differences in second language acquisition. Rowley, MA: Newbury House Publishers, Inc.

Lamendella, J. (1977). General principles of neurofunctional organisation and their manifestation in primary and non-primary language acquisition. Language Learning, 27: 155-96.

Lenneberg, E. (1967). Biological Foundations of Language. New York: Wiley.

Long, M. (1990). Maturational constraints on language development. Studies in Second Language Acquisition, 12: 251-285.

Newport, E. (1990). Maturational constraints on language learning. Cognitive Science, 14: $1-28$.

Nikolov, M. and Mihaljević Djigunović, J. (2006). Recent research on age, second language acquisition and early foreign language learning. Annual Review of Applied Linguistics, 26: 234-260.

Patkowski, M. S. (1990). Age and accent in a second language: a reply to James Emil Flege. Applied Linguistics, 11: 73-89.

Penfield, W. and Roberts, L. (1959). Speech and brain mechanisms. Princeton, N.J.: Princeton University Press.

Pollock, J-Y. (1989). Verb movement, UG and the structure of IP. Linguistic Inquiry, 20: $365-424$.

Punt, L. (1998). Adjectivale flexie en verwerving: De verschillen tussen eerste en tweede taalverwervers van het Nederlands [Adjectival inflection and acquisition: The differences between first and second language learners of Dutch, summary in English by Sharon Unsworth]. MA thesis. Utrecht: University of Utrecht.

Radford, A. (1990). Syntactic theory and the acquisition of English syntax. London: Basil Blackwell Ltd.

Radford, A. (1992). The acquisition of the morphosyntax of finite verbs in English. In J. M. Meisel (ed.). The acquisition of verb placement, 23-62. Dordrecht: Kluwer.

Schaeffer, J. (2000). Direct object scrambling and clitic placement: Syntax and pragmatics. Amsterdam: John Benjamins.

Schwartz, B. D. (1992). Testing between UG-based and problem-solving models of L2A: Developmental sequence data. Language Acquisition, 2: 1-19.

Schwartz, B. D. (2003). Child L2 acquisition: Paving the way. In B. Beachley et al. (eds.). Proceedings of the $27^{\text {th }}$ Annual Boston University Conference on Language Development, 26-50. Somerville, MA: Cascadilla Press.

Singleton, D. (2005). The critical period hypothesis: A coat of many colours. International Review of Applied Linguistics in Language Teaching, 43: 269-285.

Unsworth, S. (2002a). Differences and similarities in developmental patterns in child L1, child L2 and adult L2 acquisition. Paper presented at Experimental Linguistics Talks, Utrecht.

Unsworth, S. (2002b). Young (and older) L2 learners and Dutch scrambling. In M. Cazzoli Goeta, S. Pourcel and L. Van Espen (eds.). Proceedings of the Fifth Durham 
Postgraduate Conference in Theoretical and Applied Linguistics, 205-214. Durham: School of Linguistics and Language.

Weerman, F. (2002). Dynamiek in taal en de explosie van de Neerlandistiek [Dynamics in language and the explosion of Dutch (booklet for inaugural professional lecture, English translation by Sharon Unsworth)]. Amsterdam: University of Amsterdam.

White, L. (1990/1991). The verb movement parameter in second language acquisition. Language Acquisition, 1: 337-60.

White, L. (1992). Long and short verb movement in second language acquisition. Canadian Journal of Linguistics, 37: 273-86.

White, L. (1996). Universal Grammar and second language acquisition: Current trends and new directions. In W. C. Ritchie and T. K. Bhatia (eds.). Handbook of second language acquisition, 85-116. USA: Academic Press.

White, L. (2003). Second language acquisition and Universal Grammar. Cambridge: Cambridge University Press. 


\section{Appendix 1. The Syntax Task}

I. Examples from the Grammaticality Judgment Task for Negation

Please judge each of the following sentences whether it is grammatical in English or not. From the answers, choose a) if you think it is correct in English;

b) if you are not sure or don't know or c) if you think the sentence is not correct in English.

1. My brother can not write Japanese.
a) correct
b) don't know
c) incorrect
a) correct
b) don't know
c) incorrect
a) correct
b) don't know
c) incorrect
a) correct
b) don't know
c) incorrect
a) correct
b) don't know
c) incorrect
a) correct
b) don't know
c) incorrect
a) correct
b) don't know
c) incorrect
a) correct
b) don't know
c) incorrect
a) correct
b) don't know
c) incorrect

2. My brother not can write Japanese.

3. My brother do not can write Japanese.

5. My name is not David.

7. Jana wears not a red T-shirt.

8. Jana does not wear a red T-shirt.

9. Jana not wears a red T-shirt.

II. Examples from the Grammaticality Judgment Task for Question Formation Instructions-same as above

1. Can the children play the guitar?
a) correct
b) don't know
c) incorrect
a) correct
b) don't know
c) incorrect
a) correct
b) don't know
c) incorrect
a) correct
b) don't know
c) incorrect
a) correct
b) don't know
c) incorrect
a) correct
b) don't know
c) incorrect
a) correct
b) don't know
c) incorrect
a) correct
b) don't know
c) incorrect
a) correct
b) don't know
c) incorrect

3 . Do can play the children the guitar?

4. Do they are your relatives?

5. Are they your relatives?

6 . They are your relatives?

7. Where studies Kate?

8. Where does study Kate?

9. Where does Kate study?

Note: The tests for the children and the adult group were grammatically identical. In some sentences, they only differed in the choice of vocabulary, e.g. 'school' instead of 'work'. 


\section{Appendix 2. The Morphology Task}

The Multiple Choice Test on Morphology for the L2 Children

Fill in the blanks in each sentence with the correct answer a), b) or c) from the choices underneath. Only one of the three choices offered is the correct one in English.

Hello,

My name is Toni.

1. I a student.
a) is
b) am
c) has

2. Jana my sister.
a) is
b) are
c) am

3. My eyes green.
a) is
b) are
c) have

4. We have a dog. The dog
a) cans
b) can
c) is can run fast.

5. My sister and I
a) go
b) goes
c) does go to school in the morning.

6. Jana write and sing.
a) can
b) does can
c) cans

7. She play tennis too.
a) can
b) cans
c) is can

8. Goran football in the afternoons.
a) is play
b) plays
c) play

9. My friends Goran and Mile TV every evening.
a) is watch
b) watches
c) watch

Note. The morphology test for the child and the adult group was grammatically identical. There were some differences only in vocabulary, e.g. student (for the children) and doctor (for the adults) in sentence one. 